\title{
Application of microsimulation models in the analysis of taxes and social benefits in Groatia
}

\author{
IVICA URBAN Institute of Public Finance
}

Fiscal system microsimulation models enable the simulation of taxes, social insurance contributions, and social benefits, thus allowing researchers to predict the effects of a potential reform of these fiscal instruments on the distribution of disposable income, work incentives, as well as on budgetary revenue and expenditure. Although microsimulation models are one of the key tools for academic and policy analysis in other EU countries, such models have not been systematically developed and used in Croatia so far. In September 2015 researchers from the Institute of Public Finance therefore launched the research project "Application of Microsimulation Models in the Analysis of Taxes and Social Benefits in Croatia" (hereinafter: the Project), which is outlined in this paper.

\section{INTRODUGTION}

Tax-benefit reforms require detailed preparations, specifically an estimate of the current state of affairs, identification of shortcomings, and definition of the objectives. In the period following the implementation of the reform, the results must be monitored in order to confirm that the objectives have been achieved. Microsimulation models are one of the key analytical tools for tax-benefits analysis.

The main objective of the Project is the analysis of social benefits, personal income tax, and social insurance contributions in Croatia through microsimulation models. The research shall demonstrate the effect of both existing fiscal instruments and alternatively developed ones on the poverty rates, income distribution, and the economic activity of individuals. The aim of the Project is to promote the use of these models in tax-benefit reform planning.

The paper is structured as follows: the Introduction section is followed by section 2, where the details of tax-benefit microsimulation models are explained; the subject of section 3 is EUROMOD, a model covering all EU countries; Project objectives are outlined in section 4, which is followed by the conclusion section. The concepts of social benefits and social protection are explained and the

\footnotetext{
I The Project is one of the "Installation Research Projects", financed by the Croatian Science Foundation (Project code: UIP-20I409-4096). The abbreviated Project name is AMMATSBC. For further information on the Project, refer to http://www.ijf.hr/eng/research/croatian-science-foundation-projects/I053/ammatsbc/Io62/.
} 
availability of statistical data regarding social benefits, taxes, and social insurance contributions is briefly discussed in the Appendix.

\section{MICROSIMULATION MODELS OF TAXES AND SOGIAL BENEFITS}

When analysing reforms aimed at stimulating employment, reducing poverty rates, or achieving a more equitable distribution of income, the use of microdata and microsimulation models of taxes and social benefits is indispensable. ${ }^{2}$

Microdata are data that refer to individuals and households. These are usually collected from surveys; however, they can also be obtained from administrative sources. ${ }^{3}$ Microdata provide, for each individual in the sample, information on their demographic and socioeconomic characteristics, market income, and social benefits received, as well as various other types of data.

The microsimulation model of taxes and social benefits allows for tax liabilities and social benefits to be calculated for each individual in the microdata set. The model consists of two basic elements: a) a specially prepared set of variables containing microdata; b) computer-programmed procedures and parameters for the calculation of new variables.

In practice, the first step is to simulate the baseline scenario, which reconstructs the „actual state of affairs" in the country at a specific point in time. For instance, in the 2016 baseline scenario for Croatia, taxes and social benefits for each income unit are to be calculated in accordance with the legal regulations effective in 2016. Subsequently, various reform scenarios are simulated by changing certain parameters of the baseline scenario. These scenarios are then used to assess the effect of various changes in the basic system on disposable income and other relevant variables. A comparison of the reform scenario outcomes to the baseline scenario allows us to observe the potential effect of implementing any such change in the tax and social benefits system.

\section{EUROMOD}

EUROMOD is a tax-benefit microsimulation model for EU countries. ${ }^{4}$ Several months after Croatia's EU accession, an upgrade process has begun in order to extend the EUROMOD to cover the Croatian tax-benefit system. Researchers from the Institute of Public Finance participated in this project, which was finalized at the end of 20I5.5 A new version of EUROMOD, containing modules for all EU member states, including, for the first time, Croatia, is scheduled to be released in early 2016.

EUROMOD ,is a tax-benefit microsimulation model for the European Union that enables researchers and policy analysts to calculate, in a comparable manner, the effects of taxes and benefits on household incomes and work incentives for the population of each country and for the EU as a whole. As well as

\footnotetext{
${ }^{2}$ Refer to Appendix I, where the concepts of social benefits and social protection are explained. The term "taxes", unless otherwise specified, also covers social insurance contributions.

${ }^{3}$ Anketa o dohotku stanovništva (Survey on Income and Living Conditions; Croatian Bureau of Statistics, 20I3) is currently the best source of data for Croatian tax and social benefit microsimulation. Surveys and databases of administrative bodies offer representative data on real individuals. However, hypothetical data on so-called "typical families" can also be used in microsimulation models. An example of such a model and analysis is shown by Urban (20I4).

${ }^{4}$ For EUROMOD official website, refer to https://www.euromod.ac.uk/.

${ }^{5}$ Croatian national EUROMOD team members are Ivica Urban and Slavko Bezeredi. Refer to https://www.euromod.ac.uk/about/meet-team/national-teams.
} 
calculating the effects of actual policies it is also used to evaluate the effects of tax-benefit policy reforms and other changes on poverty, inequality, incentives and government budgets."6

EUROMOD offers a unique framework for defining taxes and social benefits across countries (Figari et al., 2OI4), making it an ideal tool for the comparative analysis of different groups of countries or EU as a whole. Moreover, EUROMOD can be used for „supra-national” fiscal instrument analysis, i.e. the analysis of EUwide taxes and social benefits. The documentation on data and computer procedure preparation is detailed and publicly available, guaranteeing comparable and consistent results. The software is available free of charge to all researchers. ${ }^{7}$

EUROMOD's Croatian module will be used for the simulation of the following fiscal instruments for the period between 20II and 2015: a) social insurance contributions of employers, employees, the selfemployed, pensioners, etc.; b) personal income tax and surtax; c) the guaranteed minimum benefit (from 2014 to 2OI5), i.e. the subsistence support (from 2011 to 2OI3); d) family benefits: the child benefit, the onetime grant for newborn children, maternity and parental leave benefits; e) the unemployment benefit.

\section{PROJEGT OBJEGTIVES}

The research has three basic objectives: I) developing a microsimulation model of Croatian taxes and benefits - MICROMOD (miCROmod); 2) using MICROMOD and EUROMOD in tax-benefit analysis; 3 ) presenting the workings of microsimulation models to public administration leaders and academic researchers. ${ }^{8}$

\section{I. MiCROMOD}

MICROMOD is a microsimulation model of Croatian taxes and benefits to be developed in the course of the Project. MICROMOD will use the same programming interface as EUROMOD and will contain elements from the Croatian EUROMOD module. However, MICROMOD will also include certain additional options.

One of these options shall allow for the social benefits in the City of Zagreb to be simulated. ${ }^{9}$ As a matter of fact, local government units (counties, cities, and municipalities) in Croatia also contribute to the social protection system. Even though the expenditure at the local level is low when compared to that of the national government, some local government units, e.g. larger cities, offer dozens of various social benefit programmes for the socially disadvantaged, pensioners, the unemployed, and other groups. As, on the other hand, most municipalities and cities do not have sufficient funds for such programmes, the end result is an inter-regional horizontal inequality in terms of benefits received.

In addition, MICROMOD will also contain a „behavioural” module simulating the effect of tax-benefit instrument changes on labour supply and gross wages. „Labour supply” is an umbrella term for decisions individuals make regarding the labour market - employment status, hours of work, inactivity,

\footnotetext{
${ }^{6}$ For more information about EUROMOD, refer to https://www.iser.essex.ac.uk/euromod.

7 However, researchers need to obtain special permissions to gain access to microdata. For more information, refer to https://www.iser.essex.ac.uk/euromod/using-euromod/access/data-permissions.

${ }^{8}$ Refer to http://www.ijf.hr/eng/research/croatian-science-foundation-projects/IO53/ammatsbc/IO62/.

${ }^{9}$ EUROMOD cannot be used for the simulation of fiscal instruments on the local government level since the data used by the model - EU statistics on income and living conditions (EU-SILC) - do not enable the identification of local units where individuals reside. For the purpose of MICROMOD modelling, permission to access data regarding individuals residing in the City of Zagreb will be requested from the Croatian Bureau of Statistics.
} 
etc. In microsimulation models such as EUROMOD and MICROMOD the working hypothesis is that changes in the tax-benefit system have no impact on individuals' choices on the labour market, i.e. they are essentially „static” models. Provided that such changes are small (such as increasing personal tax allowance or benefit amount by HRK IOO), there will be no significant impact on labour supply, and the results of such a static model will be relevant. However, if changes in rates and amounts are substantial or if an existing tax (or benefit) instrument is replaced with a significantly different one, this can lead to significant changes in hours of labour supplied and employment rates. In this case, the use the „behavioural” module is necessary.

\subsection{TAX-BENEFIT ANALYSIS}

The main objective of the Project is the application of microsimulation models in the analysis of taxes and social benefits. The first step is to analyse the baseline scenario in order to establish the influence of the existing tax-benefit system on income distribution, poverty rates, and work incentives. The next step is to simulate alternative systems in order to find out how various reforms applied to certain taxes and social benefits would impact social welfare.

The four basic areas of analysis covered by the Project are:

- Supports for children. The government provides support to households with children through several social benefit instruments as well as by adjusting the tax base in the personal income tax system. How effective is this system in reducing child poverty and achieving vertical and horizontal equity, and how can the situation be improved? EUROMOD enables „policy swapping” exercises - implementing other countries' child benefit systems in the Croatian fiscal system (Levy et al., 2009). This would, for instance, enable researchers to find out how the Slovenian or Austrian system would work in the Croatian context.

- Personal income tax. This is the tax instrument that is most subject to change, specifically the levels of the personal tax allowance and tax bands. There are also frequent discussions on lowering top marginal tax rate. The objective of such changes is to increase the disposable income of citizens and stimulate official economic activity. What effect do such reforms have on the hours of labour supplied, and what effect do they have on the distribution of tax burden? This part of the analysis should provide guidelines to be applied in introducing the "optimal" personal income tax.

- Policies aimed at making work pay. Low employment rates and high unemployment and inactivity rates are a well-known issue in Croatia. One possible cause is the tax-benefit system, which actually decreases financial incentives for work. Bejaković et al. (2012) have shown that some groups of households in Croatia face very high marginal effective tax rates when a household member transitions from inactivity into employment. In other words, "work does not pay" for such households, resulting in the household member remaining inactive. ${ }^{10}$ Many EU countries have introduced in-work policies aimed at making work pay, and microsimulation models can estimate the potential effect of "make-work-pay" policies on employment rates.

- Local social benefits. Social benefits disbursed by local government units further increase marginal effective tax rates, thus „making work pay less” for certain vulnerable groups. It is necessary to identify such instruments and thus enable public administration leaders to reform certain benefits or redirect funds to other programmes.

\footnotetext{
Io Therefore, in its guidelines on the prevention and correction of macroeconomic imbalances, the European Commission recommends, among other things, the following: „Review tax and benefits systems and present an action plan to improve the reactivation of inactive and unemployed persons." (European Commission, 2015). The revision shall be done as part of the PROGRESS project „Synergetic Social System” implemented by the Ministry of Social Policy and Youth in cooperation with the United Nations Development Programme (UNDP) in Croatia.
} 


\subsection{COOPERATION WITH PUBLIC ADMINISTRATION REPRESENTATIVES AND ACADEMIC RESEARCHERS}

Special importance is given to cooperation with collaborators from public administration bodies and the academic community. On the one hand, researchers' intention is to make the public and academia familiar with the possibilities offered by microsimulation models for the implementation of fiscal policies and economic analysis and thereby encourage analysts and researchers to start using EUROMOD. On the other hand, such collaboration also allows gathering as much information as possible, which in turn will help to further develop MICROMOD and upgrade EUROMOD.

Model builders have to familiarize themselves with the laws, regulations, and instructions governing the tax-benefit system in Croatia. However, modelling also requires familiarity with how laws and regulations are applied in practice, and to achieve that, researchers need answers to specific questions of a practical nature. Cooperation with the representatives of government ministries and social protection authorities has already been initialized with the aim of obtaining those answers. In later stages of the project, such collaboration should also extend to local government representatives.

Administrative statistical data on taxes and benefits play a very important role in the development of the microsimulation model. They are important for the „calibration” and „validation” of the model in the baseline scenario - i.e. for verifying whether the model reflects real outcomes well. Basic data for most taxes and benefits are publicly available; however, cooperation with social protection authorities is required to obtain access to more detailed data. ${ }^{\text {II }}$

Such collaboration shall involve the organization of round tables, presentations, and consultations.

\section{Conclusion}

Changes to the tax system, the social security contribution system, and the social protection system occur very frequently in Croatia. Insufficiently well-prepared reforms often result in the need for subsequent regulatory changes, which in turn make the system more complex and may result in new irregularities. Inadequate assessment of effect on budget revenue and expenditure leads to budget amendments. Moreover, without careful ex post analyses of the reform, it is not possible to conclusively assess whether the reform was successful.

It is therefore imperative that sufficient time is allowed for thorough analyses, simulations, and verifications in the planning stage of the reform of the fiscal system. This is the approach advocated by the project „Application of Microsimulation Models in the Analysis of Taxes and Social Benefits in Croatia”, one of the objectives of which is the promotion of the use of microsimulation tax-benefit models in reform planning.

\section{APPENDIX I. SOGIAL PROTEGTION AND SOGIAL BENEFITS}

Social protection „includes all government and other measures and mechanisms designed to protect socially vulnerable groups such as the elderly, the sick, the disabled, the unemployed, the poor, families

II For the public availability of statistical data on social benefits and taxes, refer to Appendix 2. 
with children, etc.” (Puljiz, 200O). In 2013 the Republic of Croatia spent approximately HRK 7I.5 billion for social protection activities at all levels of government (Croatian Bureau of Statistics, 2015)..12

The abbreviated term for benefits pertaining to the social protection system used in scientific publications is social benefits. However, in Croatia, the term „social benefits” is often understood as referring only to the benefits disbursed to poor individuals and families, such as guaranteed minimum benefit, lumpsum grants, food vouchers, etc. It is therefore important to note that the concept of social benefits is much wider and includes all cash and in-kind benefits for retirement, disability, sickness, for families and children, the unemployed, the socially excluded, etc. It is irrelevant in this case whether such benefits come from the compulsory social security contributions system (such as the old-age pension or the sick leave benefit) or are financed exclusively from the general budget (such as the child benefit).

\section{APPENDIX 2. AVAILABILITY OF STATISTICAL DATA ON SOGIAL BENEFITS AND TAXES}

Generally speaking, national and local government authorities are obliged to provide their citizens with detailed information on their activities. In the area of social protection and taxes, such information should include: I) catalogues or lists of social benefits, social insurance contributions, and taxes; 2) total number of beneficiaries/taxpayers and contribution payers; 3) total amounts of social benefits, contributions, and taxes.

Basic data on social benefits, taxes, and social insurance contributions can be found in national and local government budgetary documents. The data should, however, also be made available on the websites of these institutions in the form of statistical reports.

National government bodies responsible for social protection (the Ministry of Social Policy and Youth, the Croatian Pension Insurance Institute, the Croatian Health Insurance Fund, the Croatian Employment Service, etc.) publish statistical reports that contain data on total amounts and number of beneficiaries for most social benefits disbursed. To make it easier for citizens and analysts to navigate through the many reports and publications, it would be useful to prepare a summary listing of all the various benefits in one place, as well as to enable access to the relevant statistics. A good example is given by the Slovenian Ministry of Labour, Family, Social Affairs and Equal Opportunities, whose website contains links to all web pages containing statistical data regarding social protection. ${ }^{\mathrm{I} 3}$

Data detailing the beneficiaries and total amounts disbursed for some social benefits are not publically available. For instance, a case in point are some fifteen maternity and parental benefits (including benefits for adoptive parents) disbursed in accordance with the provisions of the Maternity and Parental Benefits Act for which there are no publically available data. One exception is the total benefit amount for "statutory and additional maternity leave benefit"; however, no data on the number of beneficiaries are available. ${ }^{14}$ Moreover, there is no available data regarding benefits paid in accordance

\footnotetext{
I2 The Croatian Bureau of Statistics' research is based on the ESSPROS methodology, where social protection expenditures are divided into eight categories: sickness/healthcare benefits, disability benefits, old-age benefits, survivors' benefits, family/children benefits, unemployment benefits, housing benefits, and social exclusion benefits not elsewhere classified.

${ }^{13}$ Available at http://www.mddsz.gov.si/si/uveljavljanje_pravic/statistika/. One of the pages

(http://www.mddsz.gov.si/si/uveljavljanje_pravic/statistika/druz_prejemki_zavarovanje_sv/) contains time series data for a dozen different benefits for families and the elderly; it shows annual beneficiary numbers and total amounts for each benefit in the period from 1994 (or the year of benefit introduction) to 2014.

${ }^{14}$ As per Articles 12 and 24 of the Maternity and Parental Benefits Act (refer to the statistical reports of the Croatian Health Insurance Fund).
} 
with the provisions of the Act on the Protection of Military Personnel and Civilians Disabled in War payable to persons disabled in war, both military and civilian..$^{15}$

Data on total taxes and compulsory social security contributions can be obtained from reports published by the Ministry of Finance; however, this data is highly aggregated. Data on the number of taxpayers, as well as on total contribution amounts for different taxpayer categories (there are more than twenty of them), should be published. As regards personal income tax, data that should be published include the number of taxpayers, total personal income amounts, tax allowances and reliefs amounts, final tax liabilities, etc.

The availability of data regarding social benefits at the level of local government units has not been analysed. A quick look at official pages tells us that cities do not publish statistical reports comparable to those published by state ministries and social insurance funds, leaving users no option other than to turn to the city budgets for detailed information. For example, the City of Rijeka and the City of Zagreb provide data on the number of beneficiaries and amounts for specific social protection programmes in their budgetary documents. However, such data should cover multiannual periods, should be published in separate statistic reports, and be available on cities', municipalities', and counties' official web sites.

\section{REFERENGES}

Bejaković, P. [et al.], A., 20I2. Isplati li se raditi u Hrvatskoj? Revija za socijalnu politiku, I9 (I), pp. 83 - 92. CBS, 20I3. Poverty Indicators 2OII. First release, no. I4. I. 3.

CBS, 20I5. Social Protection in the Republic of Croatia, 2013. First release IO. I. 5.

European Commission, 2015. Country Report Croatia 2015. - Including an In-Depth Review on the Prevention and Correction of Macroeconomic Imbalances.

Figari, F., Paulus, A., and Sutherland, H., 20I4. Microsimulation and Policy Analysis. In: A. B. Atkinson and F. Bourguignon, eds. Handbook of Income Distribution. Elsevier.

Government of the Republic of Croatia, 20I3. Izvješće o provedbi Zakona o pravima hrvatskih branitelja iz Domovinskog rata i članova njihovih obitelji za 20I3. godinu.

Levy, H., Morawski, L., and Myck, M., 2009. Alternative tax-benefit strategies to support children in Poland. In: O. Lelkes and H. Sutherland, eds. Tax and benefit policies in the enlarged Europe: assessing the impact with microsimulation models. Farnham, Surrey, UK; Burlington, VT: Ashgate.

Puljiz, V., 200o. Organizacija socijalne zaštite u Europskoj uniji. Revija za socijalnu politiku, 7 (3), pp. 363 - 370.

Urban, I., 20I4. Supports for households with children. Newsletter, No. 88.

Zakon o rodiljnim i roditeljskim potporama (Maternity and Parental Benefits Act), NN 85/o8, IIO/o8, 34/II, 54/I3, I52/I4).

Zakon o zaštiti vojnih i civilnih invalida rata (Act on the Protection of Military Personnel and Civilians Disabled in War), NN 33/92, 77/92, 58/93, 2/94, 76/94, IO8/95, 82/OI, IO3/O3, I48/13).

${ }^{15}$ Data on benefits payable to military personnel disabled in times of peace can be found in a separate report (Government of the Republic of Croatia, 2013). 